\title{
Application Polyurethane and Stone Germanium as a Deterrent Risk of Osteoarthritis on Knee Decker
}

\author{
Fazar Dinata
}

\begin{abstract}
To know the effectiveness of the application of polyurethane and stone germanium on Decker as a deterrent of knee osteoarthritis risk. This paper proposes general overview of an application of polyurethane and germanium stones on Decker as a deterrent knee osteoarthritis risk. The methods that are given in this paper are based on literature by seeing the potential application of polyurethane and germanium stones. The results presented in this paper, although not derived from the real application, are obtained from literatures according to the right knee joint flexion and good blood flow to the knee that can reduce Osteoarthritis risk by 5 times.
\end{abstract}

Index Terms-Germanium stone, osteoarthritis, polyurethane.

\section{INTRODUCTION}

Development in Indonesia has driven a massive change in the health condition of the citizen. This change occurs among demographic and apidemiological transition. Demographic transition is a change in structure of the pattern/population characterized by the increasing number of citizen, age over 60 years due to the increasing of Life Expectancy (UHH). Life Expectancy's Fig in Indonesia increased from 64.71, in 1995 to 2000 , to 67.68 , in 2000 to 2005 . Moreover, the percentation of adults citizen above 60 years increased from 16 million (7.6\%) in 2000 to 18.4 million (8.4\%) in 2005 .

Data from Bureau of Census of U.S reveals that Indonesia is expected to be the largest of adult citizen throughout the world between 1990 and 2005, that is, 414\%. Indonesia's Life Expectancy is estimated to reach 70 years old in 2015 to 2020. The diseases associated with aging factor are often called as degenerative disease, including Osteoarthritis.

Osteoarthritis is the most common joint disease that ever found throughout the globe, including in Indonesia. This disease causes pain and disability in the joint that definitely will disturb many activities. In the U.K, about 1.3-1.75 million are experiencing symptoms of Osteoarthritis while in U.S, one 1 out of 7 adults suffered from Osteoarthritis. In Western, Osteoarthritis has been the second rank after cardiovascular diseases as a result of physical disability. Overall, about $10 \%$ to $15 \%$ adults over 60 years are suffering from Osteoarthritis.

Osteoarthritis is a progressive disease with a slow progression, characterized by changing in metabolic, biochemical, structural joint cartilage and surrounding tissues, causing disfunction of the joint. The common abnormality in

Manuscript received September 22, 2012; revised October 26, 2012.

Fazar Dinata is with the Metallurgy and Material Department, University of Indonesia (e-mail: fazar.dinata@ui.ac.id).
Osteoarthritis is the damage of cartilage that can be followed by a thickening of the subchondral bone, growth of osteophyte, damage of ligament mild inflammation in the synovium. This will lead to effusion.

Pain comes due to several things, unprotected periostenum, mikrofracture subchondral, nerves ending irritation in the synovium by Osteophytes, periarticular muscle spasm, decreasing blood flow in bone and increasing of intraosseous pressure and synovitis followed with the release of prostaglandins, leukotrienes, and various sitokins.

Based on research, there is a surprising result that Osteoarthritis can not be cured, but the patient's quality of life can be improved. Hence, improving the quality life of the patient is the only way. But, that should be a second option. The first choice is to prevent the occurrence of Osteoarthritis.

\section{METHODS}

Osteoarthritis can not be cured, but the quality of patient's life can be improved by live in healthy lifestyle. This healthy lifestyle means that one should concern to how the knee joint is positioned appropriately according to the safe limit of joint flexion so that it will increase the blood flow to the knee. This is true according to the previous studies. Based on previous studies, joint position and blood flow are enough to affect the health of the knee so that it can avoid the diseases of Osteoarthritis. Based on previous research in the knee, the wrong movement and the blood circulatory problem in the knee trigger by strenuous physical activity. Based on these studies, the risk of Osteoarthritis caused by less precise joint position and abnormal blood flow is five times greater than one that people who did not do any strenuous activity. Starting from that fact, this study aims to prevent problems with the flexion of knee joint as well as abnormal blood flow to the knee by using tools such as Decker with the main material derived from polyurethane and germanim stone. In this paper efforts are being made to achieve this goal is merely finding information related to the expected results of the tool application by means of literature study.

\section{DISCUSSION AND RESULTS}

Based on osteoarthritis disease risk factors from previous studies, the following datas are obtained:

\begin{tabular}{|l|l|l|}
\hline No & Risk factor & Impact \\
\hline 1 & Obesity & 2.51 times riskier \\
\hline 2 & History of knee trauma & 2,90 times riskier \\
\hline 3 & Strenuos physical activity & 5 times riskier \\
\hline
\end{tabular}


From the datas, it can be concluded that strenuous physical activity habit is the biggest risk factor for everyone who is affected by osteoarthritis. This occurs during heavy physical activity performed by a person that changes the position of the knee joint -crosses the line or not the right angle of flexion of knee joint. Moreover, when one performs physical activity, the blood is not flowing smoothly to the knee. Unfortunately, the knee is in need of nutrition obtained from the flowing blood. This is why the knee may not obtain a maximum nutrition.

A major change in the knee angle is known as one ROM or range of movement. ROM for the straight leg $0^{\circ}$, while the legs bend ROM is $140^{\circ}$. Men and women have a different $\mathrm{ROM}, \mathrm{ROM}$ in men ranged from $-6^{\circ}$ to $140^{\circ}$ angle. On the other hand, women ranged from $-5^{\circ}$ to $143^{\circ}$. Every different activity has a different knee flexion angle. Some studies explain that $93^{\circ}$ of knee flexion is required to rise from a seated position, $106^{\circ}$ of knee flexion need to tie shoelaces, $135^{\circ}$ of flexion need to properly take a shower. As for running, it requires range of $2^{\circ}-70^{\circ}$ flexion angle. If the position of the joints that occurs over the corner, then there will be a lameness.

When the knee is taking into number of the load or physical activity, it will be obtained the following data.

From the data presented, it can be seen that each activity has a flexion angle of the knee and its own burden. Based on the data, the strain has the biggest burden for the ascent of mount and the knee flexion angle squad has the greatest neccesary rather than the other activities. Strain ascent of mount has a load of 3.6 BW (body weight) and the squad has a flexion angle of $92^{\circ}$. Based on data obtained angles are allowed to knee flexion which ranged between $8.5^{\circ}-92^{\circ}$, therefore, in order to avoid the risk of knee Osteoarthritis, in doing each activity, the knee flexion angle should be at range $8.5^{\circ}-92^{\circ}$.

Another factor of the risk of Osteoarthritis is caused by blood flow substandard knee area. Blood flow on the knee is associated with providing nutrients to every tissue on the knee. One of the objectives of this nutrient is for collagen formation that would be useful to cartilage form. The cartilage has a function to strengthen the joint. Besides, blood flows to the knee, can also create any tissue on it to get optimal function.

This paper purposes a solution to the prevention of Osteoarthritis risks. This paper also tries to resolve the problems associated with flexion angle and blood flow as a major factor of Osteoarthritis. Settlement is going to do to apply polyurethane material and germanium stone in the form of Decker knee. This Decker hopefully can set the angle of flexion to the match position and facilitate blood flow to the knee.

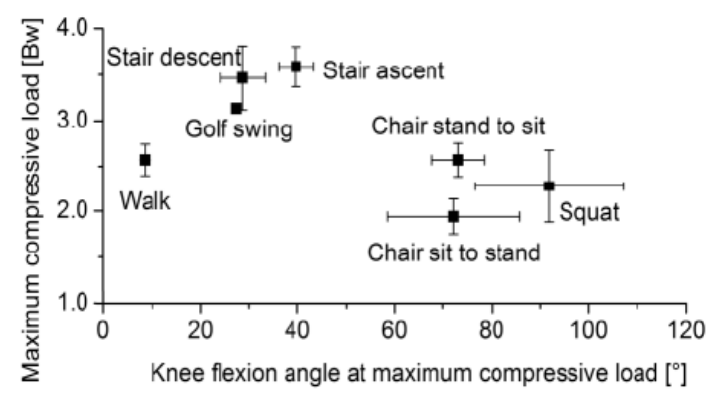

Fig. 1. Max compressive load and the knee flexion angles in which they occur for each of the selected activities ( \pm 1 std dev).

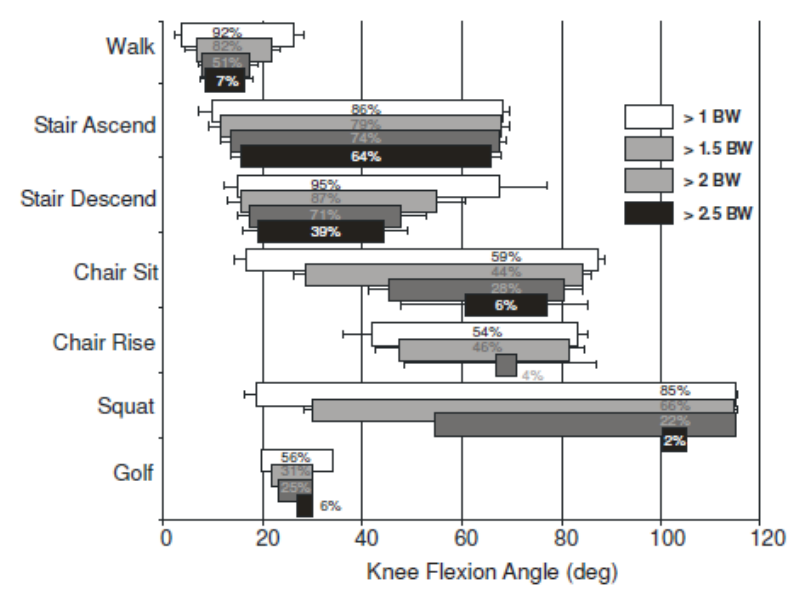

Fig. 2. Range of flexion angles for activities with total compressive forces exceeding 1-2.5BW ( \pm 1 std dev). Percentage of stance phase above these values is embedded in each bar.

Polyurethane Decker is chosen as the main material because it can be designed to be able to adjust the angle of flexion of the knee joint in order to not exceed the limits specified. Design capability is based on the properties of polyurethane which is resistant to rips with the power of 500 lbs/inch to $100 \mathrm{lbs} / \mathrm{inch}$, resistant to sweat, have a water absorption of $0.1 \%$ to $0.9 \%$ and has a break elongation of $600 \%$ to $720 \%$. In connection with its application to the knee Decker, polyurethane will set the ideal position of the knee flexion angle. If the angle of flexion is beyond ideal condition, the polyurethane material will sustain the movement and not be elastic. This is based on the strength of the knee joint when it is moved and by the strength of the polyurethane material. Polyurethane material commonly used as a silencer can also be used as a buffer for the knee during an impact. Polyurethane material is also very flexible, so it does not interfere in the user's activity. In addition, polyurethane material is resistant to weather conditions, so it can be used in any weather and circumstances, including when swimming. The technical preparation will be studied further.

For a blood flow problem, the materials related to this case are germanium stone. So, in the knee Decker, the material that acts for improving blood is germanium stone. Germanium stone is natural rock that has high semiconductor properties. Germanium has 4 electron shells and 32 electrons. Electrons lose energy and go up to the shell from fourth shell to the first shell. Shell will lose their energy and will be thrown into the current of the human body. This electricity will enrich the electric current on the human body and makes us feel fresh.. Germanium can discharge negative ions to hold steady electrical current of the human body. We need to maintain our body's electrical currents continuously at the required level to ensure the uninterrupted flow of our energy. That's why, after a long hard day of work or even after a tough sport, we will feel very tired. This is because we are running out of negative ions. By filling back to a steady rate, we will be able to avoid fatigue and improve the welfare of the body. In its application, germanium stone lines have been assigned following the blood flow through the knee

Here is the main design of Decker made of polyurethane and germanium stone: 


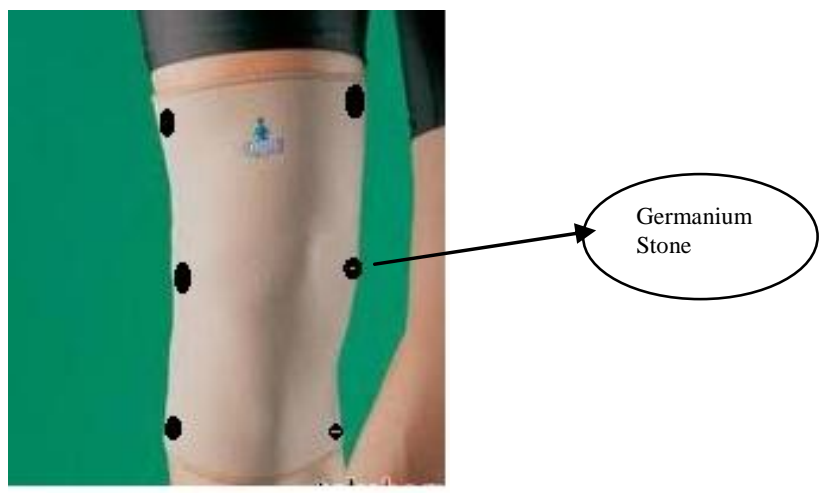

Based on previous research, it is known that people who perform strenuous physical activities have a risk five times greater risk of osteoarthritis disease. If it is studied deeply, it is due to a knee flexion angle and blood flow to the knee. So if the problems in the knee flexion angle at the knee and the blood flow can be solved by Decker from polyurethane material and germanium stone, then Decker can significantly reduce the risk of osteoarthritis disease.

\section{REFERENCES}

[1] D. R. Boedhi and M. H. Hadi, Geriatri (Ilmu Kesehatan Usia Lanjut). Jakarta: Balai Penerbit FK - UI, pp. 1-7, 1999.

[2] S. Bambang, "Osteoartritis selayang pandang," Dalam Temu Ilmiah Reumatologi, Jakarta, pp. 27-31, 2003.

[3] J. Y. Reginster, The Prevalence and Burden of Osteoarthritis. Rheumatology, vol. 41, no. 1, pp. 3-6, 2002.

[4] J. M. Palletier and J. P. Palletier, Effect of Aceclogenac and Diclofenac on Inflamatory in Human Osteoarthritis. Clinical Drugs Investigation, vol. 14 , no. 3, pp. 326-332, 1997.

[5] A. P. Sylvia and M. W. Lorraine, Patofisiologi, Konsep Klinis Prosesproses Penyakit, Edisi 4. Jakarta: Penerbit Buku Kedokteran EGC, pp. 1218-1222, 1995.

[6] K. N. Laubenthal, A quantitative analysis of knee motion during activities of daily living, Phys Ther, vol. 52, no. 1, pp. 34-43, 1972.

[7] P. J. Rowe et al., Knee joint kinematics in gait and other functional activities measured using flexible electrogoniometry: how much knee motion is sufficient for normal daily life? Gait and Posture, vol. 12, pp. 143-155, 2000.

[8] C. Dyrby et al., in Vivo Knee Loading Measured by an Instrumented Total Knee Replacement During Activities OF Daily Living.

[9] E. P. Paharani, Faktor - factor resiko Osteoarthtritis, vol. 123, 2007.

[10] H. S. Allan, Biomaterial Science, vol. 69, 2004.
[11] I Globe Healt Care. (2012). How Germaium Benefits Your Health [Online]. Available: http://www.iglobehealthcare.com/vital-ion/132germanium-benefits.html

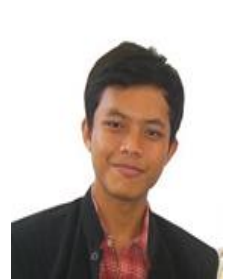

Fazar Dinata was born in Depok, $10^{\text {th }}$ June $1993 . \mathrm{He}$ is now undergoing study at the Faculty of Mechanical Engineering, University of Indonesia majoring in metallurgy and materials. In mid-2012, he had stepped semester 3 campus activities in addition to lecturing, he has a wide range of other activities, such as one of teachers in one area Bimbel Depok, and he also teaches privately, and then she was also involved in several organizations on campus and off campus. Now he is one of the participants of the PPSDMS NF regional 1 Jakarta -scholarship for Youth Movement. Regarding writing, at least five titles he published with a variety of themes. However, from a variety of themes were written, the theme of the application of a material is the most popular.

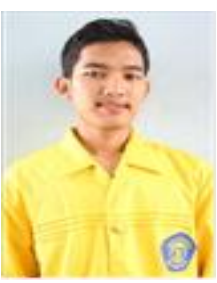

Febrian Adi Tri W. is a student at Departement of Chemical Engineering, Faculty of Engineering in University of Indonesia. He was born on Bekasi Februari $10^{\text {th }} 1992$. he concerns in petroleum society, otomotive, and as University moslem activity.Now, he has activity as leader of Islamic Learning at Faculty moslem institution named "FUSI FTUI", staff of Man of Resource and Comunnity at IATMI SM UI, and member of Chem-E-Car UI especially in Fuel Cell Car. He also one of participant in PPSDMS NF regional 1 Jakarta. The Achievement ever reached is Runner up of Chemistry Nasional Science Olimpiade level town in Bekasi in 2009, $3^{\text {rd }}$ youth Cooperation named "Pemuda Pinilih" level Provice in west Java Indonesia in 2009, he has job beside his activity as student of university and member of organization. Now, He works partime at Bimbel Nurul Fikri as Chemistry teacher.

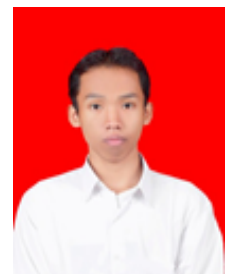

Mohammad Sofa Khodi was born in Sampang $27^{\text {th }}$ April 1993. An active student in Chemical Engineering, Faculty of Engineering, University of Indonesia. He's currently active in several Engineeing organizations on campus Active in 2012 as a staff Green Community of Indonesia and active in the Chemical Engineering Department Association IMTK FTUI. His writings are in several fields including mass media, but particularly about chemical engineering issue in his website. Now he's become a program participant's strategic human resource development (PPSDMS) which is a scholarship student achievement. 